\title{
Effectivity of near-peer teaching in training of basic surgical skills - a randomized controlled trial
}

\author{
Zsolt Pintér ${ }^{1}$, Dániel Kardos ${ }^{1,2}$, Péter Varga ${ }^{1,3}$, Eszter Kopjár ${ }^{1}$, Anna Kovács ${ }^{1}$, Péter Than ${ }^{4}$, Szilárd Rendeki ${ }^{1,5}$,
}

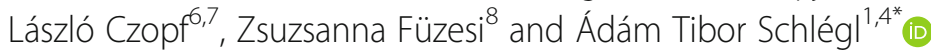

\begin{abstract}
Background: Near-peer teaching (NPT) is a special way of teaching where the tutor is one or more academic years ahead of the person being tutored. The literature agrees on the benefits of the method, but there are only a few publications examining its effectiveness using objective methods. The aim of our study was to examine the effectiveness of NPT in the training of basic surgical skills.

Methods: We included 60 volunteer students who participated in a $20 \times 45$ min long surgical skills course. Based on the results of a pre-course test, we randomly divided the students into six equal groups. All groups completed the same curriculum, with three groups being assisted by a NPT tutor. After the course, they completed the same test as at the beginning. The exams were recorded on anonymized videos and were blindly evaluated. The students' satisfaction was monitored using a self-administered online anonymous questionnaire. Statistical analysis was performed using the Mann-Whitney and Wilcoxon tests.

Results: Overall, student performance improved with completion of the course (from 119.86 to 153.55 points, $p<0.01$ ). In groups where a NPT tutor assisted, students achieved a significantly better score (37.20 vs. 30.18 points improvement, $p=0.036)$. The difference was prominent in surgical knotting tasks ( $14.73 \mathrm{vs} .9 .30$ points improvement, $p<0.01$ ). In cases of suturing (15.90 vs. 15.46 points) and laparoscopy (7.00 vs. 4.98 points), the presence of the NPT tutor did not significantly affect development. Based on student feedback, although students positively assessed the presence of NPT, it did not significantly improve students' overall satisfaction since it was already 4,82 on a scale of 5 in the control group.
\end{abstract}

Conclusions: Overall, involving a NPT tutor had a positive impact on student development. An outstanding difference was observed in connection with knotting techniques.

Keywords: Near-peer teaching, Surgical education, RCT, Basic surgical skills, Suturing

\footnotetext{
* Correspondence: schlegl.adam@pte.hu

${ }^{1}$ Medical Simulation Education Centre, University of Pécs, Medical School, Pécs, Hungary

${ }^{4}$ Department of Orthopaedics, University of Pécs, Medical School, Akác street 1., Pécs H-7632, Hungary

Full list of author information is available at the end of the article
}

(c) The Author(s). 2021 Open Access This article is licensed under a Creative Commons Attribution 4.0 International License, which permits use, sharing, adaptation, distribution and reproduction in any medium or format, as long as you give appropriate credit to the original author(s) and the source, provide a link to the Creative Commons licence, and indicate if changes were made. The images or other third party material in this article are included in the article's Creative Commons licence, unless indicated otherwise in a credit line to the material. If material is not included in the article's Creative Commons licence and your intended use is not permitted by statutory regulation or exceeds the permitted use, you will need to obtain permission directly from the copyright holder. To view a copy of this licence, visit http://creativecommons.org/licenses/by/4.0/ The Creative Commons Public Domain Dedication waiver (http://creativecommons.org/publicdomain/zero/1.0/) applies to the data made available in this article, unless otherwise stated in a credit line to the data. 


\section{Background}

Near-peer teaching (NPT) is gaining popularity as an effective teaching method in medicine, especially in anatomy and basic sciences. Furthermore, its benefits have already been documented in detail in surgery, paediatrics, pathology, orthopaedics and family medicine [1-10].

Peer education after Topping can be defined as individuals from a similar social group who, as nonprofessional educators, help each other in learning and learn by teaching themselves [11]. Although there is no uniformly accepted definition of NPT, the already existing descriptions basically agree that it is a form of peer education in which a student in the teaching role participates in the same training but is at least one academic year ahead in his or her studies than the student in the student role $[12,13]$.

A widely accepted principle of the method is to exploit the benefits of cognitive and social congruence. Cognitive congruence (i.e., similar prior knowledge and study experiences) allows the use of language that is certain to be understood by the learner, as well as the appropriate choice of the logic and conceptual framework of the explanation, which helps the learner to understand. Social congruence (i.e., a similar role) allows for the creation of a calm and easy educational environment [13-15].

Although several publications have reported positive changes (such as the development of confidence or understanding) using the NPT method, these are mostly based on subjective impressions and opinions. Only a few studies were found that examined the effectiveness of NPT using objective and prospective techniques [1, 2, 16-18].

We have found just one publication by Preece et al. examining the effectiveness of NPT in teaching surgical skills. They found the use of peer-assisted learning as an effective, cheap and sustainable way to teach suturing skills, although they did not involve control group in their study [19].

\section{Methods}

The aim of our research was to objectively investigate the effectiveness of NPT related to basic surgical skills.

\section{Main hypothesis}

Involvement of NPT in surgical education improves the exam results of the students participating in the course.

\section{Secondary hypothesis}

Involvement of NPT in education improves the satisfaction of students participating in the course.

\section{Study design}

Single-blinded, prospective, parallel group, randomized controlled trial.

\section{Population of the study}

Our sample size calculation was based on the test results of previous years. The study sample estimate envisaged the involvement of 58 students, estimating a 3-point difference between the study and control groups $(\alpha=0.05$, $\beta=0.1$ ). Based on these, we included 60 volunteer students (30 women and 30 men, with a mean age of $22.6 \pm 2.2$ years) in the study. The criteria for student participation was the successful completion of the 'Basics of Surgery' course for the third-year pre-clinical curriculum of our university; however, the student should not complete the surgery summer practice after the fourth-year. So, participants were third- and fourth-year medical students.

Three volunteer peer educators were also involved in the research. The NPT tutors were sixth-year medical students who had successfully completed the surgical subjects included in our university's compulsory curriculum, completed the simulation training centre's own NPT preparation course (including an exam with testtraining), and had a minimum of 1 year of NPT experience (NPT tutors).

The teaching staff consisted of three practicing clinical physicians working in the manual medical profession with at least 3 years of teaching experience (instructors).

Video recordings were evaluated with the involvement of three senior instructors who had a minimum of 10 years of teaching experience and 5 years of examination experience as clinical specialists working in the manual profession (senior instructors).

The study was approved by the Institutional Ethical Review Board (7719-PTE 2019).

\section{Protocol including procedural details}

Prior to the course, all students underwent a preliminary aptitude test. In doing so, we assessed their existing skills in surgical knotting techniques, basic suture techniques, and basic laparoscopic skills. Knotting and suturing exercises were recorded on video, which was evaluated anonymously by the three senior instructors. We took into account the average of the scores given by the instructors. Laparoscopic skills were scored based on an evaluation sheet issued by the simulator.

1. Based on the scores obtained we divided the students into 4 groups (from poor to excellent performance). After this we have assigned a number between 1 and 6 randomly to the students within each group separately. Thereby six homogenous 
group of 10 with almost equal initial scores were created.

2. An NPT tutor and instructor were assigned to the three groups by drawing lots (study group), and then an instructor was assigned to the remaining three groups by drawing lots (control group). So, each instructor had a group where a NPT tutor would help with their work and one where they would hold the lesson alone.

3. All groups took a $20 \times 45$ min course with the same timeline on different weeks, including:

a. Deepening the knowledge of the instruments and introduction of suture materials $-45 \mathrm{~min}$

b. Two-handed (surgical) and one-handed (Viennese) knotting $-4 \times 45 \mathrm{~min}$

c. Simple knot stitch, instrumental (apodactyl and atraumatic) knot and Zagreb's knot $-2 \times 45 \mathrm{~min}$

d. Vertical mattress (Donati) and Allgöwer-Donati sutures $-2 \times 45 \mathrm{~min}$

e. Intracutaneous running sutures $-3 \times 45 \mathrm{~min}$

f. Laparoscopic basic (device knowledge and camera use) $-2 \times 45 \mathrm{~min}$

g. Laparoscopic skill development $-4 \times 45 \mathrm{~min}$

h. Free practice according to the student's preference $-2 \times 45$ minutes

4. The skills of the students were assessed on the day after the end of the course in the same way as before the course.

5. At the end of the course, students completed a selfadministered online anonymous questionnaire that measured their opinion about the course and the application of the NPT on a Likert scale of 5.

\section{Protocol of the evaluation}

Surveys were conducted before and on the day after the course under the supervision of the instructors. Students completed the assignments independently, without assistance, which were videotaped so that the student's identity could not be identified (Fig. 1).
Videos were evaluated by senior instructors based on the Objective Structured Assessment of Technical Skill (OSATS) after they were settled and randomly ordered. To evaluate knotting, we used a slightly modified version of the criteria published by Shen et al. (Tables 1 and 2), and we developed our own criteria system to evaluate the sutures (Table 3) [20]. Prior to the course, we took test recordings with the help of the NPT tutors and instructors to check the usability of the scorecard, and the evaluators learned how to use the method. Training was continued until the senior instructors received an $\alpha$ value above 0.95 in intraclass correlation studies.

\section{Tasks of exam}

1. Two-handed knot in the tension tissue model, with the latex rubber band of knotting trainer (three pieces with the right hand and three pieces with the left hand) evaluation according to OSATS (Table 1)

2. One-handed knot in the torn fabric model, with the magnetic hook of knotting trainer (three pieces with the right hand and three pieces with the left hand) evaluation according to OSATS (Table 2)

3. Simple interrupted suture, with atraumatic suturing material and instrumental knot with suture pad (three pieces) evaluation according to OSATS (Table 3)

4. Vertical mattress (Donati) suture, with atraumatic suturing material and instrumental knot with suture pad (three pieces) evaluation according to OSATS (Table 3)

5. Intracutaneous running suture, with atraumatic suturing material and instrumental knot with suture pad $(4 \mathrm{~cm})$ evaluation according to OSATS (Table 3)

6. Performing a "Peg transfer-Level 1" task on a LapVR v4.0.399.46816 (CAE Healthcare, Sarasota, FL, USA) simulator (the better result of two attempts) evaluation based on the evaluation sheet

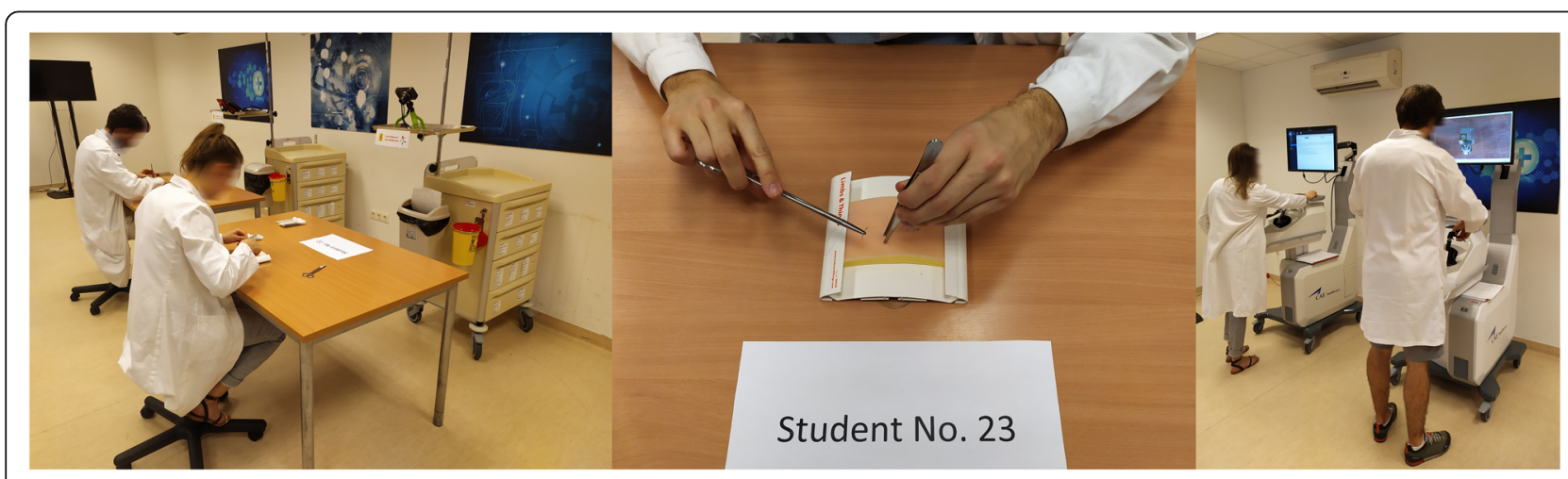

Fig. 1 Post-course exam; left - recording of the suturing practices; middle - screenshot from the record; right - laparoscopic skills practices 
Table 1 Assessment of two-handed knot-tying techniques

\begin{tabular}{|c|c|c|c|}
\hline & 1 point & 2 points & 3 points \\
\hline $\begin{array}{l}\text { Tension of knot-tying } \\
\text { cords during the method }\end{array}$ & Mostly loose & Mostly tight & Always tight \\
\hline Motion & Many unnecessary moves & Less unnecessary movement & No unnecessary movement \\
\hline Direction of the first knot & Wrong (knot failure) & Not ideal (knot failure) & Good \\
\hline Direction of knots & Always the same & Partially alternating & Alternating \\
\hline Positioning of the knot & Did not push down & Mostly pushed down & Always pushed down \\
\hline Respect of tissue & $\begin{array}{l}\text { The latex rubber band always moved in the direction } \\
\text { of the hand (knotting material is too tight) }\end{array}$ & $\begin{array}{l}\text { Unnecessary movements of } \\
\text { trainer's latex rubber band }\end{array}$ & $\begin{array}{l}\text { The latex rubber band did not } \\
\text { move towards the hand }\end{array}$ \\
\hline Stability of the knot & Loose loop, the edges of the rubber did not line up & $\begin{array}{l}\text { The edges of the rubber just } \\
\text { fit together }\end{array}$ & $\begin{array}{l}\text { Good stability, the edges of } \\
\text { the rubber fit together }\end{array}$ \\
\hline Time & $60 s<$ & $45-60 s$ & $<45 s$ \\
\hline
\end{tabular}

issued by the tool. If all the conditions were met, then the time allotted for the task was scored (onetenth of the total time required to complete the task was subtracted from 35).

Statistical analysis was performed using the MannWhitney $U$ Test and Wilcoxon signed- rank tests (IBM SPSS v23, IBM Corp., Armonk, NY, USA). The RANDBETWEEN function of Microsoft Excel v14.0.6112.5000 (Microsoft Corp., Redmond, WA, USA) was used for randomization. $P<0.05$ was considered significant.

\section{Results}

The results of the pre-course test in the control groups without the NPT tutor (the overall results of the students were 120.406 points) did not differ significantly from the study groups that included the NPT tutor (119.320 points, $p=0.679$ ).

Taking into account the overall results of the students, a significant improvement was achieved in all areas during the completion of the course (average 33.690 point improvement, $p<0.001$ ) (Table 4).
In the groups where the NPT tutor assisted the teaching, students achieved a significantly greater improvement (30.180 vs. 37.200 point improvement, $p=0.036$ ); however, this difference was significant only for the tasks related to knotting (9.300 vs. 14.733 point improvement, $p=0.003$ ). There were no significant differences in tasks related to suturing (15.900 vs. 15.497 point improvement) and laparoscopic basics (4.980 vs. 7.000 point improvement) (Tables 5 and 6).

Based on the feedback of students, although students positively assessed the presence of demonstrators (4.80 on a Likert scale of 5), this did not significantly affect their satisfaction (4.77 vs. $4.83, p=0.28)$ (Table 7).

\section{Discussion}

In the course of our research, we assessed the effect of the technical application of NPT on the development and satisfaction of students using an objective method among homogenized groups.

\section{Main hypothesis}

We successfully proved our main hypothesis that the involvement of a peer educator in the teaching of basic

Table 2 Assessment of one-handed knot-tying techniques

\begin{tabular}{|c|c|c|c|}
\hline & 1 point & 2 points & 3 points \\
\hline $\begin{array}{l}\text { Tension of knot-tying cords during the } \\
\text { method }\end{array}$ & Mostly loose & Mostly tight & Always tight \\
\hline Motion & Many unnecessary moves & Less unnecessary movement & No unnecessary movement \\
\hline Direction of the first knot & Wrong (knot failure) & Not ideal (knot failure) & Excellent \\
\hline Direction of knots & Always the same & Partially alternating & Alternating \\
\hline Positioning of the knot & Did not push down & Mostly pushed down & Always pushed down \\
\hline Respect of tissue & $\begin{array}{l}\text { The magnetic hook } \\
\text { elevated }\end{array}$ & $\begin{array}{l}\text { The magnetic hook elevated } \\
\text { slightly }\end{array}$ & The magnetic hook did not elevate \\
\hline Stability of the knot & $\begin{array}{l}\text { Loose loop, fell off the } \\
\text { hook }\end{array}$ & The knot slipped off the hook & $\begin{array}{l}\text { Good stability, knot did not slip off the } \\
\text { hook }\end{array}$ \\
\hline Time & $60 s<$ & $45-60 \mathrm{~s}$ & $<45 s$ \\
\hline
\end{tabular}


Table 3 Score system used for assessment of sutures

\begin{tabular}{|c|c|c|c|}
\hline & 1 & 2 & 3 \\
\hline Hold the needle at $1 / 3$ & Not even once & Sometimes & Always \\
\hline $\begin{array}{l}90^{\circ} \text { between the surface and the } \\
\text { needle }\end{array}$ & Not even once & Sometimes & Always \\
\hline Appropriate usage of forceps & Wrong & Intermediate & Excellent \\
\hline $\begin{array}{l}\text { Appropriate direction and } \\
\text { technique of knotting }\end{array}$ & Wrong & Intermediate & Excellent \\
\hline Appropriate tightness of the knot & Wrong & Intermediate & Excellent \\
\hline Appropriate position the skin edges & Wrong & Intermediate & Excellent \\
\hline $\begin{array}{l}\text { Appropriate distance from the skin } \\
\text { edge }\end{array}$ & Wrong & Intermediate & Excellent \\
\hline $\begin{array}{l}\text { Appropriate distance between } \\
\text { sutures }\end{array}$ & Wrong & Intermediate & Excellent \\
\hline Respect of tissue & $\begin{array}{l}\text { Unnecessarily damaged } \\
\text { the tissue }\end{array}$ & $\begin{array}{l}\text { Handled the tissue carefully, but accidentally caused } \\
\text { inadvertent damage }\end{array}$ & $\begin{array}{l}\text { Did not damage the } \\
\text { tissue }\end{array}$ \\
\hline Time and motion & $\begin{array}{l}\text { Did not finish within } 4 \\
\text { min }\end{array}$ & Done in time, but a lot of unnecessary movements & $\begin{array}{l}\text { Done in time, worked } \\
\text { effectively }\end{array}$ \\
\hline Maintenance of asepsis & Did not reach & Strived for it, but accidentally violated it & Reached \\
\hline SUM & & & \\
\hline
\end{tabular}

surgical skills significantly improved the exam results of the students.

The course where also an NPT tutor attended the students' education showed significantly better results in the tasks related to knotting, while no differences were found between the study and control groups in the tasks related to suturing and basic laparoscopic techniques. This controversial result may be due to several reason. The need for a high degree of personalized attention to the teaching of knotting can be one of them. By breaking it down into its elements and presenting professional hand movements individually, it is easier to learn the right technique. In suturing and laparoscopy, the appropriate technique and video assistance can also be effectively demonstrated for larger groups. At the same time, the instructor can check the end result more easily in larger groups, and the self-checking processes are easier as well. Viewing the finished seam line or the feedback provided by the laparoscopy simulator, it easily reveals type errors without the instructor. Another reason can be, that the post-course exam result of the suture skills reached the $88,2 \%$ of the possible maximum points in the control group leaving only a few potential for more improvement in the study group. We also need to acknowledge that 6 session of $45 \mathrm{~min}$ of laparoscopy education is probably a too short amount of training time for such complex skills to see the effect of NPT.

Although we did not find any publication in the literature, we reviewed the ones that we could directly

Table 4 Aggregate results of students' surgical skills pre- and post-course

\begin{tabular}{|c|c|c|c|c|c|}
\hline & Pre-course & Post-course & Improvement & Wilcoxon (p) & $\mathbf{Z}$ \\
\hline Overall results & 119.863 & 153.553 & $33.690^{*}$ & $<0.001$ & -6.736 \\
\hline Knotting & 27.767 & 39.783 & $12.017^{*}$ & $<0.001$ & -6.740 \\
\hline Two-handed knotting & 13.583 & 19.333 & $5.750^{*}$ & $<0.001$ & -6.724 \\
\hline One-handed knotting & 14.183 & 20.450 & $6.267^{*}$ & $<0.001$ & -6.514 \\
\hline Sutures & 72.533 & 88.217 & $15.683^{*}$ & $<0.001$ & -6.618 \\
\hline Simple interrupted & 24.067 & 29.467 & $5.400^{*}$ & $<0.001$ & -6.205 \\
\hline Vertical mattress (Donati) & 24.667 & 29.517 & $4.850^{*}$ & $<0.001$ & -5.799 \\
\hline Intracutaneous running & 23.800 & 29.233 & $5.433^{*}$ & $<0.001$ & -6.342 \\
\hline Laparoscopic basics & 19.563 & 25.553 & $5.990^{*}$ & $<0.001$ & -6.283 \\
\hline
\end{tabular}

The average points and the results of the Wilcoxon signed-rank test ( ${ }^{*}$ significant difference between pre- and post-course results) 
Table 5 The results of the pre- and post-course tests of the control and study groups

\begin{tabular}{|c|c|c|c|c|c|c|c|c|c|c|c|c|}
\hline & \multicolumn{4}{|c|}{ Pre-course } & \multicolumn{4}{|c|}{ Post-course } & \multicolumn{4}{|c|}{ Improvement } \\
\hline & \multicolumn{2}{|c|}{ Control group } & \multicolumn{2}{|c|}{ Study group } & \multicolumn{2}{|c|}{ Control group } & \multicolumn{2}{|c|}{ Study group } & \multicolumn{2}{|c|}{ Control group } & \multicolumn{2}{|c|}{ Study group } \\
\hline & pt & $\%$ & pt & $\%$ & pt & $\%$ & pt & $\%$ & pt & $\%$ & pt & $\%$ \\
\hline Overall results & 120,41 & $68,0 \%$ & 119,32 & $67,4 \%$ & 150,59 & $85,1 \%$ & 156,52 & $88,4 \%$ & 30,18 & $17,1 \%$ & 37,20 & $21,0 \%$ \\
\hline Knotting & 28,73 & $59,9 \%$ & 26,80 & $55,8 \%$ & 38,03 & $79,2 \%$ & 41,53 & $86,5 \%$ & 9,30 & $19,4 \%$ & 14,73 & $30,7 \%$ \\
\hline Two-handed knotting & 13,73 & $57,2 \%$ & 13,43 & $56,0 \%$ & 18,33 & $76,4 \%$ & 20,33 & $84,7 \%$ & 4,60 & $19,2 \%$ & 6,90 & $28,8 \%$ \\
\hline One-handed knotting & 15,00 & $62,5 \%$ & 13,37 & $55,7 \%$ & 19,70 & $82,1 \%$ & 21,20 & $88,3 \%$ & 4,70 & $19,6 \%$ & 7,83 & $32,6 \%$ \\
\hline Sutures & 71,37 & $72,1 \%$ & 73,70 & $74,4 \%$ & 87,27 & $88,2 \%$ & 89,17 & $90,1 \%$ & 15,90 & $16,1 \%$ & 15,47 & $15,6 \%$ \\
\hline Simple interrupted & 23,77 & $72,0 \%$ & 24,37 & $73,8 \%$ & 29,33 & $88,9 \%$ & 29,60 & $89,7 \%$ & 5,57 & $16,9 \%$ & 5,23 & $15,9 \%$ \\
\hline Vertical mattress & 24,63 & $74,6 \%$ & 24,70 & $74,8 \%$ & 29,07 & $88,1 \%$ & 29,97 & $90,8 \%$ & 4,43 & $13,4 \%$ & 5,27 & $16,0 \%$ \\
\hline Intracutaneous running & 22,97 & $69,6 \%$ & 24,63 & $74,6 \%$ & 28,87 & $87,5 \%$ & 29,60 & $89,7 \%$ & 5,90 & $17,9 \%$ & 4,97 & $15,1 \%$ \\
\hline Laparoscopic basics & 20,31 & $67,7 \%$ & 18,82 & $62,7 \%$ & 25,29 & $84,3 \%$ & 25,82 & $86,1 \%$ & 4,98 & $16,6 \%$ & 7,00 & $23,3 \%$ \\
\hline
\end{tabular}

pt Point, \% Percentage of the possible maximum points

compare to our results. They are consistent with our general findings that the application of NPT could improve students' exam scores.

In the study by Preece et al., senior medical students delivered two suturing workshops to 35 students. They had significant improvement in the number of the completed number of sutures and inter-suture distance. All students found the workshop helpful and the teaching environment relaxed. Furthermore, $87 \%$ of the students reported that the workshop increased their interest in a surgical career [19].

In randomized controlled studies, Hudsen and Tokin demonstrated that NPT tutors can be at least as effective in teaching history and physical examination skills as graduate doctors, as well as others in the field of resuscitation training, bladder catheterization and intravenous cannulation [16-18].

In basic science, Gallan et al. (biochemistry), Jackson et al. (physiology), and Sawyer et al. (first-year curriculum) demonstrated the effectiveness of the use of additional NPT courses [21-23]. Alcamo et al. demonstrated the effectiveness of the USMLE Step 1 preparatory NPT course [24]. However, these studies are limited by the fact that NPT education was present as a complement, an additional learning opportunity.

In their retrospective study, Cate et al. compared the groups taught by NPT tutors and faculty for 36 courses (in the topic of circulation and metabolism) and found higher scores in 29 cases compared the groups taught by only NPT tutors [15]. The effectiveness of the method for teaching musculoskeletal competence has also been demonstrated with the involvement of orthopaedic residents [2].

In the reviewed literature, only Batchelder et al. did not find the application of the NPT method effective in terms of student exam scores, although they also reported that students in the programme felt more prepared and "more familiar with the

Table 6 The changes between the pre- and post-course tests of the control and study groups

\begin{tabular}{llllll}
\hline & Control group & Study group & Difference & Mann-Whitney (p) & Z \\
\hline Overall results & 30.180 & 37.200 & $7.020^{*}$ & 0.036 & -2.100 \\
Knotting & 9.300 & 14.733 & $5.433^{*}$ & 0.003 & -2.949 \\
$\quad$ Two-handed knotting & 4.600 & 6.900 & $2.300^{*}$ & 0.011 & -2.536 \\
$\quad$ One-handed knotting & 4.700 & 7.833 & $3.133^{*}$ & 0.004 & -2.849 \\
Sutures & 15.900 & 15.467 & -0.433 & 0.865 & -0.170 \\
$\quad$ Simple interrupted & 5.567 & 5.233 & -0.333 & 0.789 & -0.267 \\
$\quad$ Vertical mattress (Donati) & 4.433 & 5.267 & 0.833 & 0.528 & -0.631 \\
$\quad$ Intracutaneous running & 5.900 & 4.967 & -0.933 & 0.422 & -0.802 \\
Laparoscopic basics & 4.980 & 7.000 & 2.020 & 0.156 & -1.420 \\
\hline
\end{tabular}

The average points and results of the Mann-Whitney $U$ test (*significant difference between the control and study groups) 
Table 7 Results of students' feedback

\begin{tabular}{|c|c|c|c|c|c|c|}
\hline & $\begin{array}{l}\text { Control } \\
\text { group }\end{array}$ & $\begin{array}{l}\text { Standard } \\
\text { deviation }\end{array}$ & $\begin{array}{l}\text { Study } \\
\text { group }\end{array}$ & $\begin{array}{l}\text { Standard } \\
\text { deviation }\end{array}$ & $\begin{array}{l}\text { Mann-Whitney } \\
\text { (p) }\end{array}$ & $\mathbf{Z}$ \\
\hline $\begin{array}{l}\text { 1. Do you consider the material taught to be useful for your future } \\
\text { profession? }\end{array}$ & 4.90 & 0.31 & 4.80 & 0.41 & 0.28 & -1.08 \\
\hline 2. How do you judge the level of the course? & 4.50 & 0.68 & 4.43 & 0.73 & 0.74 & -0.33 \\
\hline 3. Have you found the course interesting? & 4.70 & 0.47 & 4.60 & 0.62 & 0.66 & -0.44 \\
\hline 4. Do you think the lessons were easy to understand? & 4.87 & 0.35 & 4.87 & 0.35 & 1.00 & 0.00 \\
\hline 5. Did you have enough time for practicing? & 4.97 & 0.18 & 4.83 & 0.38 & 0.09 & -1.71 \\
\hline $\begin{array}{l}\text { 6. Did the course leader/demonstrator pay enough attention to } \\
\text { you? }\end{array}$ & 4.83 & 0.75 & 4.83 & 0.38 & 0.26 & -1.13 \\
\hline $\begin{array}{l}\text { 7. How do you feel and how much have your manual skills } \\
\text { developed? }\end{array}$ & 4.67 & 0.55 & 4.47 & 0.63 & 0.18 & -1.33 \\
\hline 8. All in all, how would you evaluate the course? & 4.83 & 0.46 & 4.77 & 0.50 & 0.51 & -0.66 \\
\hline 9. Was the presence of the NPT tutor on the course useful? & & & 4.70 & 0.53 & & \\
\hline 10. Could the NPT tutor help your progress? & & & 4.67 & 0.55 & & \\
\hline $\begin{array}{l}\text { 11. All in all, how would you judge the presence of the } \\
\text { demonstrator? }\end{array}$ & & & 4.8 & 0.41 & & \\
\hline
\end{tabular}

Average result, standard deviation and results of the Mann-Whitney U Test

style of exam questions" when there were NPT tutors [25].

\section{Secondary hypothesis}

Our results were insufficient to judge possible change in student's satisfaction since the overall satisfaction of the control group reached 4,83 on a scale of 5 leaving no room for more improvement. However, students, in line with the available international literature, found the application of the NPT technique useful and felt it helped their development $[1,3,7]$.

\section{Limitations}

Based on our result it can not be declared that the reason of the significant improvement is the NPT as method, and not just the involving of an extra tutor ("workforce"), although exploring the reasons was not aim of this study.

The senior instructor who evaluated the admissions was aware that she was looking at taking a pre- or postcourse exam, which could affect her evaluation. However, the main issue of the present study was not to assess the overall improvement achieved during the course, but to compare the study and control groups, for which the evaluation was completely blind.

The personality of the demonstrator and instructor may have influenced the result. Although in the case of the instructor, we tried to eliminate this by the fact that all instructors also participated in the training of one control and one study group. At the same time, we tried to further reduce this effect by forming six groups and involving several instructors and demonstrators.
Cross-examination may be a more ideal choice to answer this question. But due to the nature of the curriculum, we thought this would be very difficult to do.

\section{Conclusions}

We could confirm that the presence of a peer educator (NPT tutor) had a positive impact on student development.

Based on the results of our research, the application of the NPT technique can be a cost-effective and mutually beneficial way to increase the impact of basic surgical skills' training.

Abbreviations

NPT: Neer-peer teaching; OSATS: Objective Structured Assessment of Technical Skill; SUM: Summary; pt.: Point

\section{Acknowledgements}

We are grateful to the staff of the Medical Simulation Education Centre, especially Péter Szücs, for their help with the exam recordings.

We would like to state that the OSATS scores used in this study were already mentioned but not published in a recent paper of the research group. The study by Schlégl et al. was performed and published during the time of data processing and interpretation of this research [26].

\section{Authors' contributions}

P.Zs: helped building the study design, take part as NPT tutor, performed the statistical analyses, put together the final manuscript. K.D., V.P: take part as instructor, reviewed the manuscript. K.E., A.K: take part as NPT tutor, reviewed the manuscript. T.P, R.Sz, C.L: reviewed the study design, take part as senior instructor, reviewed the manuscript. F.Zs: reviewed the study design, verified the statistical analyses, designed the student's feedback study, reviewed the manuscript. S.Á.T: designed the study, take part as instructor, verified the statistical analyses, helped putting together the manuscript. All authors read and approved the final manuscript.

\section{Funding}

This work was supported by the Hungarian Government [grant numbers TUDFO/51757-1/2019-ITM, 2020-4.1.1-TKP2020 and NTP-NFTÖ-20-B-0137] The founder granted the necessary consumables and labor cost for the study. 


\section{Availability of data and materials}

The datasets generated and/or analysed during the current study are not publicly available due data protection of the participants but are available from the corresponding author on reasonable request.

\section{Declarations}

\section{Ethics approval and consent to participate}

The study was approved by the Institutional and Regional Ethical Review Board of University of Pécs (7719-PTE 2019). Written informed consent was obtained from study participants. All participant agreed to take part in the study, and approved to use their data for research purposes.

\section{Consent for publication}

Not applicable.

\section{Competing interests}

No benefits in any form have been received or will be received from a commercial party related, directly or indirectly. The authors declare that there are no potential conflicts of interest in connection with this paper.

\section{Author details}

${ }^{1}$ Medical Simulation Education Centre, University of Pécs, Medical School, Pécs, Hungary. ${ }^{2}$ Department of Paediatrics, University of Pécs, Medical School, Pécs, Hungary. ${ }^{3}$ Department of Primary Health Care, University of Pécs, Medical School, Pécs, Hungary. ${ }^{4}$ Department of Orthopaedics, University of Pécs, Medical School, Akác street 1., Pécs H-7632, Hungary. ${ }^{5}$ Department of Operational Medicine, University of Pécs, Medical School, Pécs, Hungary. ${ }^{6} 1$ st Department of Medicine, University of Pécs, Medical School, Pécs, Hungary. ${ }^{7}$ Dean's Office, University of Pécs, Medical School, Pécs, Hungary. ${ }^{8}$ Department of Behavioural Sciences, University of Pécs, Medical School, Pécs, Hungary.

\section{Received: 26 August 2020 Accepted: 2 March 2021}

Published online: 12 March 2021

\section{References}

1. Shenoy A, Petersen $\mathrm{KH}$. Peer tutoring in preclinical medical education: a review of the literature. Med Sci Educ. 2020;30:537-44. https://doi.org/10.1 007/s40670-019-00895-y.

2. Schiff A, Salazar D, Vetter C, Andre J, Pinzur M. Results of a near-peer musculoskeletal medicine curriculum for senior medical students interested in orthopedic surgery. J Surg Educ. 2014;71:734-7. https://doi.org/10.1016/j. jsurg.2014.01.007.

3. Rashid A, Chan SC, Choa G, Eboreime O. Evaluating the effectiveness of using near-peer tutors in teaching first-year medical students. Future Healthc J. 2019;6(Suppl 2):24. https://doi.org/10.7861/futurehosp.6-2s-s24.

4. Alberti $H$, Rosenthal J, Kirtchuk L, Thampy $H$, Harrison M. Near peer teaching in general practice: option or expectation? Educ Prim Care. 2019;30:342-6. https://doi.org/10.1080/14739879.2019.1657363.

5. Musbahi A, Sharpe A, Straughan R, Ong S, Alhaddabi A, Reddy A. A nearpeer regional surgical teaching programme designed by medical students, delivered by junior doctors. Med Educ Online. 2019:24:1583969. https://doi. org/10.1080/10872981.2019.1583969.

6. Gottlieb Z, Epstein S, Richards J. Near-peer teaching programme for medical students. Clin Teach. 2017;14:164-9. https://doi.org/10.1111/tct.12540.

7. Karamaroudis S, Poulogiannopoulou E, Sotiropoulos MG, Kalantzis T, Johnson EO. Implementing change in neuroanatomy education: organization, evolution, and assessment of a near-peer teaching program in an undergraduate medical school in Greece. Anat Sci Educ. 2020. https:// doi.org/10.1002/ase.1944

8. Jenkinson A, Smith A, Doyle S, Gorman K, Murphy S. Near peer teaching in a paediatric healthcare setting. Ir Med J. 2019;112:1009 PMID: 31651137.

9. Tayler N, Hall S, Carr NJ, Stephens JR, Border S. Near peer teaching in medical curricula: integrating student teachers in pathology tutorials. Med Educ Online. 2015;20:27921. https://doi.org/10.3402/meo.v20.27921.

10. Burgess A, McGregor D, Mellis C. Medical students as peer tutors: a systematic review. BMC Med Educ. 2014;14:115. https://doi.org/10.1186/14 72-6920-14-115.
11. Topping KJ. The effectiveness of peer tutoring in further and higher education: a typology and review of the literature. High Educ. 1996;32:32145. https://doi.org/10.1007/BF00138870.

12. Bulte C, Betts A, Garner K, Durning S. Student teaching: views of student near-peer teachers and learners. Med Teach. 2007;29:583-90. https://doi. org/10.1080/01421590701583824.

13. Cate OT, Druning S. Dimensions and psychology of peer teaching in medical education. Med Teach. 2007;29:546-52. https://doi.org/10.1080/ 01421590701583816

14. Cate OT, Druning S. Peer teaching in medical education: twelve reasons to move from theory to practice. Med Teach. 2007;29:591-9. https://doi.org/1 0.1080/01421590701606799.

15. Cate OT, van de Vorst I, van den Broek S. Academic achievement of students tutored by near-peers. Int J Med Educ. 2012;3:6-13. https://doi. org/10.5116/ijme.4f0c.9ed2.

16. Tolsgaard MG, Gustafsson A, Rasmussen MB, Høiby P, Müller CG, Ringsted C. Student teachers can be as good as associate professors in teaching clinical skills. Med Teach. 2007;29:553-7. https://doi.org/10.1080/01421590701682 550.

17. Perkins GD, Hulme J, Bion JF. Peer-led resuscitation training for healthcare students: a randomised controlled study. Intensive Care Med. 2002;28:698700. https://doi.org/10.1007/s00134-002-1291-9.

18. Hudson JN, Tonkin AL. Clinical skills education: outcomes of relationships between junior medical students, senior peers and simulated patients. Med Educ. 2008;42:901-8. https://doi.org/10.1111/j.1365-2923.2008.03107.x.

19. Preece $\mathrm{R}$, Dickinson EC, Sherif $\mathrm{M}$, et al. Peer-assisted teaching of basic surgical skills. Med Educ Online. 2015;20:27579. https://doi.org/10.3402/meo. v20.27579.

20. Shen Z, Yang F, Gao P, et al. A novel clinical-simulated suture education for basic surgical skill: suture on the biological tissue fixed on standardized patient evaluated with Objective Structured Assessment of Technical Skill (OSATS) tools. Invest Surg. 2018;31:333-9. https://doi.org/10.1080/0894193 9.2017.1319994

21. Gallan AJ, Offner GD, Symes K. Vertical integration of biochemistry and clinical medicine using a near-peer learning model. Biochem Mol Biol Educ. 2016;4:507-16. https://doi.org/10.1002/bmb.20972.

22. Jackson TA, Evans DJ. Can medical students teach? A near-peer-led teaching program for year 1 students. Adv Physiol Educ. 2012;36:192-6. https://doi.org/10.1152/advan.00035.2012.

23. Sawyer SJ, Sylvestre PB, Girard RA, Snow MH. Effects of supplemental instruction on mean test scores and failure rates in medical school courses. Acad Med. 1996;71:1357-9. https://doi.org/10.1097/00001888-19961200000021.

24. Alcamo AM, Davids AR, Way DP, Lynn DJ, Vandre DD. The impact of a peerdesigned and -led USMLE Step 1 review course: improvement in preparation and scores. Acad Med. 2010;85(Suppl 10):45-8. https://doi.org/1 0.1097/ACM.0b013e3181ed1cb9.

25. Batchelder AJ, Rodrigues CM, Lin LY, Hickey PM, Johnson C, Elias JE. The role of students as teachers: four years' experience of a large-scale, peer-led programme. Med Teach. 2010;32:547-51. https://doi.org/10.3109/0142159X.2 010.490861.

26. Schlégl ÁT, Pintér Z, Kovács A, et al. Teaching basic surgical skills using homemade tools in response to COVID-19. Acad Med. 2020. https://doi. org/10.1097/ACM.0000000000003586

\section{Publisher's Note}

Springer Nature remains neutral with regard to jurisdictional claims in published maps and institutional affiliations. 